\title{
A proposed chemical mechanism for biological phosphate removal in activated sludge treatment of wastewater
}

\author{
DC van der Post and CF Schutte* \\ Water Utilisation Division, Department of Chemical Engineering, University of Pretoria, Pretoria 0002, South Africa
}

\begin{abstract}
This paper presents an alternative for the "all biological" phosphate removal model. It is postulated that a chemical substance in wastewater reacts with orthophosphate under anaerobic conditions to make the so-called luxury uptake of phosphorus possible in biological nutrient removal (BNR) activated sludge plants. Experimental evidence indicates that the reaction product, an organic phosphate, is the phosphate species that is taken up by organisms in the process of biological phosphate removal. The research on which this paper is based, forms part of a Ph.D. study and further research to confirm the initial observations and to identify the chemical agent involved in biological phosphorus removal is continuing.
\end{abstract}

Keywords:

\section{Introduction}

Biological phosphate removal in activated sludge processes was first reported by Levin et al. (1972), Barnard (1974) and Fuhs and Chen (1975), amongst others. Since then extensive research by a great number of people has led to the generally accepted model of phosphate uptake in activated sludge processes designed for biological phosphate removal. An up-to-date account of this is given by Grady et al. (1999).

Explanations had been offered for excess phosphate removal, e.g. that activated sludge organisms, especially Acinetobacter, could use stored energy in the form of poly-phosphate while passing through an aerobic zone (Nicholls and Osborne, 1979). Gerber et al. (1986), in laboratory experiments, demonstrated the role of acetates and other short-chain carbon compounds in biological phosphate removal processes.

Knowledge of the biological as well as biochemical aspects of phosphate uptake is fundamental for a thorough understanding of this complicated process. However, there appears to be something lacking in the model for biological phosphate removal. Terms such as "luxurious phosphate uptake" and "excess phosphate removal", which are used in the present context, appear to indicate that there is some kind of contradiction in the existing model. In this respect, the following comment is noteworthy: "A nutrient removal plant is a complex system in which the different system elements, processes and compounds often exhibit interaction in a complex manner; resolution of one problem may bring into focus, or create, another problem - it is most unlikely that a 'final' solution will ever be attained" (Wentzel et al., 1991).

In the present study evidence was found of the role of an unidentified organic substance $X$ in sewage effluent that apparently has gone unnoticed to date because there is no mention of it in the literature. The substance in question could exist in a reduced state

\footnotetext{
* To whom all correspondence should be addressed.

푱+2712 420 3571; fax: +2712 362 5089; e-mail: cschutte@eng.up.ac.za Received 4 April 2002; accepted in revised form 20 February 2003.
}

under conditions of low redox potential $(-30 \mathrm{mV})$ or in an oxidised state under conditions of relatively high redox potential $(+40 \mathrm{mV})$. The presence of the oxidised organic substance $\mathrm{X}$ can be demonstrated in effluents such as trickling filter effluent. When a sample is acidified by adding $10 \% \mathrm{H}_{2} \mathrm{SO}_{4}$ and $\mathrm{KI}$ solution in the presence of $\mathrm{X}$, iodine is liberated which could be titrated with $0,025 \mathrm{~N}$ $\mathrm{Na}_{2} \mathrm{~S}_{2} \mathrm{O}_{3}$, using starch as indicator. Control samples of trickling filter influent liberate no iodine when treated in a similar way, even when nitrate is added to obtain approximately the same $\mathrm{NO}_{3}-\mathrm{N}$ concentration as is present in the trickling filter effluent.

$\mathrm{X}$ can also be produced chemically in settled sewage. When settled sewage, after addition of $10 \mathrm{mg} / \mathrm{l} \mathrm{NO}_{3}-\mathrm{N}$, is left in contact with $\mathrm{Fe}$ granules, formation of $\mathrm{X}$ can be demonstrated after about $1 \mathrm{~h}$. A similar result is obtained when $1 \%(\mathrm{v} / \mathrm{v})$ saturated $\mathrm{HgCl}_{2}$ is added to settled sewage in order to prevent any biological activity.

Without elaborating on the proposed chemical mechanism at this stage, it should be pointed out that formation of $\mathrm{X}$ is accompanied by a reduction of nitrate to ammonia. It appears that Fe metal in this case acts as catalyst for the chemical reduction of nitrate to ammonia by a yet-to-be-identified substance in sewage effluent, which itself is oxidised in the process.

\section{Proposed chemical model for the role of $X$ in biological phosphate removal}

Progress with identification of $\mathrm{X}$ is in an advanced stage and will be reported at a later date. For the present the different oxidation states of $\mathrm{X}$ will be indicated by $\mathrm{X}_{\mathrm{ox}}$ and $\mathrm{X}_{\mathrm{red}}$. It is postulated that $\mathrm{X}$ in sewage effluent is involved in a chemical reaction with dissolved orthophosphate in the anaerobic stage of the activated sludge process. Under low redox conditions such as those that exist in the anaerobic zone, the oxidation state of $\mathrm{X}$ could be indicated as $\mathrm{X}_{\mathrm{red}}$ and the resulting reaction product with orthophosphate, as $\mathrm{X}_{3} \mathrm{PO}_{4}$. The formation of $\mathrm{X}_{3} \mathrm{PO}_{4}$ is considered a prerequisite for phosphate uptake in the biological phosphate removal process. In the case of the oxidised state, i.e. $X_{o x}$, no reaction with dissolved orthophosphate would be possible.

The laboratory tests discussed below were performed in an attempt to demonstrate the proposed chemical mechanism. 


\section{Laboratory tests}

\section{Batch activated sludge tests}

The purpose of these tests was to compare phosphate removal under conditions that would promote formation of $\mathrm{X}_{3} \mathrm{PO}_{4}$ with phosphate removal under conditions that would obstruct formation of $\mathrm{X}_{3} \mathrm{PO}_{4}$. A prerequisite was that tests had to be done in such a manner that the normal functioning of the organisms responsible for phosphate removal would not be detrimentally affected in any way during the experiments.

Gerber et al. (1986) used batch activated sludge tests to demonstrate the role that acetate and similar short-chain carbon compounds play in biological phosphate removal. In a similar vein batch tests were used in the present study to demonstrate a chemical "link" in the process of biological phosphate removal.

To demonstrate this mechanism, the batch tests had to be performed in such a way that the oxidation state of $X$ could be altered from the reduced state to the oxidised state without affecting the phosphate-removing organisms. This was achieved by first separating the sludge from the liquid, then altering the oxidation state of $\mathrm{X}$ in the liquid phase and finally, adding the sludge back to the liquid phase again. All relevant factors with respect to the organisms remained unchanged, except for the oxidation state of $\mathrm{X}$ that was changed from the reduced to the oxidised state.

Having established that redox reactions that take place in sewage treatment, e.g. in trickling filters, could be simulated by chemical means, it was possible to demonstrate the significance of these reactions in the biological phosphate removal process. The reasoning was that anaerobic conditions would result in the formation of $X_{\text {red }}$. If this reaction could be reversed by using Fe metal as explained before, it would be possible to establish the significance of the $\mathrm{X}_{\mathrm{red}} \leftrightarrow \mathrm{X}_{\mathrm{ox}}$ system in the biological phosphate removal process. The assumption was that $\mathrm{X}_{\text {red }}$ (reduced state) is essential for biological phosphate removal and if this is changed to $\mathrm{X}_{\mathrm{ox}}$ (oxidised state) it would obstruct biological phosphate removal.

The redox reactions could be represented as follows:

Anaerobic conditions: $\mathrm{X}_{\mathrm{ox}} \rightarrow \mathrm{X}_{\mathrm{red}}$

Aerobic conditions: $\quad \mathrm{X}_{\mathrm{red}}^{\mathrm{ox}} \rightarrow \mathrm{X}_{\mathrm{ox}}^{\mathrm{red}}$

\section{Laboratory procedures}

The main objective of the experiments was to change the oxidation state of $X$ from $X_{\text {red }}$ in mixed liquor to $X_{o x}$, without changing any of the other variables that are favourable for biological phosphate uptake. To achieve this it was necessary to separate the solids and the liquid of activated sludge samples. A 10 I sample of mixed liquor was taken from the anaerobic basin of the Daspoort, Pretoria activated sludge plant. An aliquot of $500 \mathrm{ml}$ at a time was filtered through Whatman No. 41 filter paper. A volume of about $480 \mathrm{ml}$ filtrate was obtained, i.e. approximately $20 \mathrm{ml}$ liquid was retained by the sludge on the filter paper. The filtrate was transferred to a 500 $\mathrm{ml}$ glass beaker. The filter paper with the sludge was then added to the contents of the glass beaker and the oxidation state of the liquid manipulated as explained further on, the filter paper was manoeuvred with the aid of a spatula until the sludge was freed completely and the filter paper was removed from the beaker. In the case of the controls exactly the same procedure was followed as for the tests, except that the filtrate was not subjected to contact with Fe metal. Therefore in the case of the controls the filter paper with the sludge was added immediately to the contents of the glass beaker.

The sludge and the liquid were properly mixed by stirring, dissolved $\mathrm{NaH}_{2} \mathrm{PO}_{4}$ was added to bring the total dissolved orthophosphate concentration in the mixture to around $70 \mathrm{mg} / \mathrm{l} \mathrm{PO}_{4}-\mathrm{P}$. The mixture was again stirred properly and approximately $200 \mathrm{ml}$ was immediately transferred to a polythene container, measuring $50 \mathrm{~mm}$ in diameter and $150 \mathrm{~mm}$ in height. The mixture in the container was aerated with an air pump of about $80 \mathrm{l} / \mathrm{h}$ capacity for $6 \mathrm{~h}$. The rest of the mixture in the glass beaker was filtered without delay. The filtrate was labelled $\mathrm{A}_{\mathrm{i}}$. After $6 \mathrm{~h}$ aeration, the mixture in the polythene container was immediately filtered and the filtrate labelled $\mathrm{A}_{\mathrm{f}}$. The dissolved orthophosphate concentration in filtrate $\mathrm{A}_{\mathrm{i}}$ and $\mathrm{A}_{\mathrm{f}}$ respectively was determined and recorded. This was used as the first of three controls in every experiment. (The whole procedure was carried out for controls and tests alike so that there would be no difference in this respect, which could perhaps have an influence on the results obtained).

The next step was done in exactly the same way with the following variation: After about $600 \mathrm{ml}$ mixed liquor was filtered, $\mathrm{KNO}_{3}$ was added to the filtrate to bring the $\mathrm{NO}_{3}-\mathrm{N}$ concentration in the filtrate to a level of $20 \mathrm{mg} / \mathrm{l} \mathrm{N}$ maximum. The filtrate was then left in contact with Fe metal (as catalyst) in $200 \mathrm{ml}$ flat glass bottles with screw caps for $24 \mathrm{~h}$. Each bottle contained approximately $50 \mathrm{~g}$ Fe metal granules, measuring about $1 \mathrm{~mm}$ to $2 \mathrm{~mm}$ in diameter. After $24 \mathrm{~h}$ contact time the contents of the glass bottles was decanted into a $500 \mathrm{ml}$ glass beaker, leaving the Fe granules behind. Another volume of $500 \mathrm{ml}$ mixed liquor of the $10 \mathrm{I}$ sample was filtered. When filtration was complete, the filter paper with the sludge retained from the mixed liquor, was transferred to $500 \mathrm{ml}$ filtrate that had had $24 \mathrm{~h}$ Fe metal contact. The sludge was transferred from the filter paper to the filtrate as was done for the control test. The filter paper was removed, the sludge and the liquid were properly mixed by stirring, and $\mathrm{NaH}_{2} \mathrm{PO}_{4}$ was added as described above. The rest was done exactly as for the control and the filtrates in this case were labelled $\mathrm{D}_{\mathrm{i}}$ and $\mathrm{D}_{\mathrm{f}}$. A second control test was done, the only difference being that $20 \mathrm{mg} / \mathrm{l} \mathrm{NO}-\mathrm{N}$ was added to the sample of mixed liquor.

A third control test was done to verify the influence of Fe contact. The sample preparation was the same as for the test, including Fe contact. The variation was that $\mathrm{KNO}_{3}$ was not added. The control tests for each experiment were as follows:

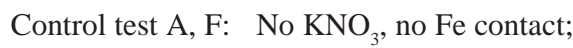

Control test B, G: $\mathrm{KNO}_{3}$, no Fe contact; and

Control test $\mathrm{C}, \mathrm{H}$ : No $\mathrm{KNO}_{3}$, Fe contact.

The results are given in Table 1.

\section{Phosphate uptake at different pH levels}

As was mentioned above the chemical reaction resulting from contacting settled sewage with Fe metal in the presence of nitrate, produces $\mathrm{NH}_{3}$. This, in turn, results in a $\mathrm{pH}$ increase of the settled sewage amounting to about one $\mathrm{pH}$ unit. Because a $\mathrm{pH}$ increase in the case of activated sludge substrate could influence phosphate uptake in the biological phosphate removal process, it was necessary to find out whether this factor was of significance in the experiments under discussion. For this purpose activated anaerobic sludge substrates at $\mathrm{pH} 7.10$ and 8.10 respectively, were tested for phosphate uptake during aeration. Except for the $\mathrm{pH}$, the experimental conditions for the two tests were exactly the same. The results obtained are given in Table 2. Final $\mathrm{PO}_{4}-\mathrm{P}$ concentrations for the two tests were identical, viz. $4.5 \mathrm{mg} / \mathrm{PO}_{4}-\mathrm{P}$. The initial $\mathrm{PO}_{4}-\mathrm{P}$ concentration for the second test was lower $(34.0 \mathrm{mg} /$

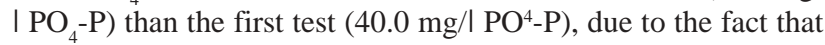




\begin{tabular}{|c|c|c|c|c|}
\hline \multicolumn{5}{|c|}{$\begin{array}{c}\text { TABLE 1A } \\
\text { Experiment 1: Fe contact } 24 \mathrm{~h}\end{array}$} \\
\hline & & $\begin{array}{l}\text { Initial } \\
\mathrm{PO}_{4}-\mathrm{P} \mathrm{mg} / \mathrm{l}\end{array}$ & $\begin{array}{l}\text { Final } \\
\mathrm{PO}_{4}-\mathrm{P} \mathrm{mg} / \mathrm{l}\end{array}$ & $\underset{\mathrm{mg} / \mathrm{l}}{\Delta \mathrm{PO}_{4}-\mathrm{P}}$ \\
\hline Control & $\begin{array}{l}\text { A } \\
B \\
\text { C }\end{array}$ & $\begin{array}{l}\mathrm{A}_{\mathrm{i}} 72 \\
\mathrm{~B}_{\mathrm{i}} 73 \\
\mathrm{C}_{\mathrm{i}} 76\end{array}$ & $\begin{array}{l}A_{f} 28 \\
B_{f} 35 \\
C_{f} 31\end{array}$ & $\begin{array}{l}44 \\
38 \\
45\end{array}$ \\
\hline Test & $\begin{array}{l}\mathrm{D} \\
\mathrm{E}\end{array}$ & $\begin{array}{l}\mathrm{D}_{\mathrm{i}} 84 \\
\mathrm{E}_{\mathrm{i}} 77\end{array}$ & $\begin{array}{l}D_{f} 66 \\
E_{f} 52\end{array}$ & $\begin{array}{l}18 \\
25\end{array}$ \\
\hline \multicolumn{5}{|c|}{$\begin{array}{c}\text { TABLE 1B } \\
\text { Experiment 2: Fe contact } 48 \mathrm{~h}\end{array}$} \\
\hline & & $\begin{array}{l}\text { Initial } \\
\mathrm{PO}_{4}-\mathrm{P} \mathrm{mg} / \mathrm{l}\end{array}$ & $\begin{array}{l}\text { Final } \\
\mathrm{PO}_{4}-\mathrm{P} \mathrm{mg} / \mathrm{l}\end{array}$ & $\underset{\mathrm{mg} / \mathrm{l}}{\Delta \mathrm{PO}_{4}-\mathrm{P}}$ \\
\hline Control & $\begin{array}{l}\mathrm{F} \\
\mathrm{G} \\
\mathrm{H}\end{array}$ & $\begin{array}{l}\mathrm{F}_{\mathrm{i}} 87 \\
\mathrm{G}_{\mathrm{i}} 92 \\
\mathrm{H}_{\mathrm{i}} 79\end{array}$ & $\begin{array}{l}\mathrm{F}_{\mathrm{f}} 53 \\
\mathrm{G}_{\mathrm{f}} 56 \\
\mathrm{H}_{\mathrm{f}} 48\end{array}$ & $\begin{array}{l}34 \\
36 \\
31\end{array}$ \\
\hline Test & $\begin{array}{l}\mathrm{I} \\
\mathrm{J}\end{array}$ & $\begin{array}{l}\mathrm{I}_{\mathrm{i}} 96 \\
\mathrm{~J}_{\mathrm{i}} 93\end{array}$ & $\begin{array}{l}\mathrm{I}_{\mathrm{f}} 88 \\
\mathrm{~J}_{\mathrm{f}} \mathrm{A}_{\mathrm{f}} 100\end{array}$ & $\begin{array}{l}8 \\
(7)\end{array}$ \\
\hline $\begin{array}{l}\mathrm{PO}_{4}-\mathrm{P} \\
\text { acid } \mathrm{m}\end{array}$ & ne & nation was & $\begin{array}{l}\text { e according t } \\
d s, 1995) \text {. }\end{array}$ & he ascorbic \\
\hline
\end{tabular}

some precipitation of phosphate occurred when $\mathrm{pH}$ for the second test was raised from 7.1 to 8.1 by adding $\mathrm{NaOH}$. However, this is considered negligible in the present context. A pH increase of 1.0 evidently was not responsible for the drastic decrease in phosphate uptake as was experienced in the case of the other experiments (Table 1A and 1B).

\section{Discussion of results from batch activated sludge tests}

The results confirm that Fe contact of the activated sludge filtrate adversely affected phosphate uptake, i.e. $\mathrm{X}_{\mathrm{ox}}$ was formed which prevented formation of $\mathrm{X}_{3} \mathrm{PO}_{4}$. The longer contact time in this case $(48 \mathrm{~h})$, resulted in a more pronounced effect on phosphate uptake. The latter amounted to less than $10 \%$ as compared to 20 to $30 \%$ for the first experiment. Reasonably good reproducibility was obtained for control tests. It became clear that the presence of 20 $\mathrm{mg} / \mathrm{NO}_{3}-\mathrm{N}$ did not harm phosphate uptake, neither did Fe contact of the filtrate when nitrate was not present.

Phosphate uptake was detrimentally affected by Fe contact only when nitrate was present in the filtrate. The longer the contact time was in the presence of nitrate, the more pronounced was the effect. The reason for this could be explained in terms of $\mathrm{X}$ formation in the filtrate. It was stated earlier that the oxidation state of the $\mathrm{X}$ could be changed by Fe contact of the activated sludge filtrate. In the anaerobic activated sludge, the $X$ would be present in its reduced state, i.e. as $X_{\text {red }}$, while it would be present as $X_{o x}$, the oxidised state, after Fe contact.

Preliminary mineral analyses done during this study indicated the presence of salts like $\mathrm{XNO}_{3}$ and $\mathrm{X}_{2} \mathrm{SO}_{4}$ that were formed under controlled laboratory conditions. It therefore seemed feasible that formation of $\mathrm{X}_{3} \mathrm{PO}_{4}$ could occur in anaerobic activated sludge. However, $\mathrm{X}_{3} \mathrm{PO}_{4}$ present in the mixed liquor would be oxidised during contact with $\mathrm{Fe}$ metal and formation of $\mathrm{X}_{\mathrm{ox}}$ would result. In
TABLE 2

Phosphate uptake: Comparison at different substrate $\mathrm{pH}$ levels

\begin{tabular}{|l|l|l|l|}
\hline $\mathbf{p H}$ & $\begin{array}{l}\text { Initial } \\
\mathbf{P O}_{4}-\mathrm{P} \mathbf{~ m g} / \mathbf{l}\end{array}$ & $\begin{array}{l}\text { Final } \\
\mathbf{P O}_{4}-\mathbf{P} \mathbf{~ m g} / \mathbf{l}\end{array}$ & $\begin{array}{l}\% \\
\text { removal }\end{array}$ \\
\hline 7.10 & 40.0 & 4.5 & 88.75 \\
8.10 & 34.0 & 4.5 & 86.76 \\
\hline
\end{tabular}

TABLE 3

Extraction of phosphate compound with chloroform: $\mathrm{PO}_{4}-\mathrm{P}$ concentration $(\mathrm{mg} / \mathrm{l})$

\begin{tabular}{|l|l|l|l|}
\hline Action & $\begin{array}{l}\text { Before } \\
\text { extraction }\end{array}$ & $\begin{array}{l}\text { After } \\
\text { extraction }\end{array}$ & $\begin{array}{l}\% \\
\text { decrease }\end{array}$ \\
\hline $\begin{array}{l}\text { Activated sludge } \\
\text { filtrate }\end{array}$ & 41.0 & 11.4 & 72.2 \\
\hline $\begin{array}{l}\text { Distilled water } \\
\text { phosphate added) }\end{array}$ & 43.8 & 40.4 & 7.8 \\
\hline $\begin{array}{l}\text { Activated sludge } \\
\text { filtrate after Fe } \\
\text { metal contact }\end{array}$ & 27.8 & 25.0 & 10.1 \\
\hline
\end{tabular}

such an event, the $\mathrm{X}_{3} \mathrm{PO}_{4}$ would be transformed into $\mathrm{X}_{\mathrm{ox}}$ plus ordinary orthophosphate, i.e. $\mathrm{Na}_{3} \mathrm{PO}_{4}$. The postulate is that $\mathrm{X}_{3} \mathrm{PO}_{4}$ is the phosphate species that is taken up by the organisms in activated sludge. When $\mathrm{X}_{3} \mathrm{PO}_{4}$ reverts back to ordinary orthophosphate as a result of Fe metal contact, it would not be suitable for uptake by the organisms in the activated sludge, and biological phosphate removal would not take place.

\section{Identification tests for $\mathbf{X}$}

The next step in an attempt to provide further evidence to support the postulate was to isolate the substance that was considered to be the chemical link in the process of biological phosphate removal, i.e. $\mathrm{X}_{3} \mathrm{PO}_{4}$. Because it was assumed to be an organic substance with strong polarity, the first option was to extract it with chloroform. A $100 \mathrm{ml}$ sample of activated sludge filtrate was acidified with $5 \mathrm{ml}$ $10 \% \mathrm{H}_{2} \mathrm{SO}_{4}$ and extracted with $50 \mathrm{ml}$ chloroform in a separating funnel. After vigorous shaking for $4 \mathrm{~min}$, time was allowed for the filtrate to separate from the chloroform.

The chloroform was first drained and then the rest was collected in a glass beaker. Orthophosphate was determined in the filtrate before and after extraction (Table 3). The orthophosphate concentration decreased by $72 \%$. Next, exactly the same procedure was followed with distilled water to which orthophosphate was added. The results in this case showed that orthophosphate concentration decreased by $8 \%$ (Table 3 ). It seemed possible that interference by chloroform could have caused this slight decrease. The decrease of $72 \%$ in the case of activated sludge filtrate, however, appeared to be largely due to a phosphate compound that was extracted with chloroform.

The above was considered to be a clear indication that a large fraction of the phosphate present in the activated sludge filtrate was in fact organic phosphate. The question now was what would happen to the organic substance when the filtrate was subjected to 
Fe contact as was done in the abovementioned batch experiments. In a further experiment $500 \mathrm{ml}$ of the activated sludge filtrate was subjected to Fe contact as described above. After $48 \mathrm{~h}$ contact the filtrate was decanted from the Fe metal granules. Because a small concentration of $\mathrm{Fe}$ oxidation products was present in the filtrate, it was filtered again. Of the clear filtrate, $100 \mathrm{ml}$ was extracted with chloroform as before. The $\mathrm{PO}_{4}-\mathrm{P}$ values obtained on the filtrate before and after extraction are given in Table 3.

Approximately $10 \%$ of the phosphate concentration was removed by extraction in this case. It was obvious that the extractable phosphate was much less after contact with $\mathrm{Fe}$ metal, i.e. $72 \%$ before Fe contact compared to $10 \%$ after Fe contact. The reason for this is believed to be that the chemical composition of the extractable portion of phosphate was altered by Fe contact. The extractable portion appeared to be the phosphate species that is involved in phosphate uptake.

Studies to identify $\mathrm{X}$ by means of different analytical techniques including GC-MS and others are currently under way and will be reported at a later stage.

\section{Additional observations on the chemical and physical characteristics of $X$}

The $\mathrm{X}$ can be distilled from an acidified sample of trickling filter effluent. It was found that $95 \%$ of $X$ in a $500 \mathrm{ml}$ sample could be concentrated in the first $100 \mathrm{ml}$ of distillate. From the distillate the $\mathrm{X}$ could be air-stripped at room temperature (approximately $25^{\circ} \mathrm{C}$ ). A small column of distillate $(25 \mathrm{ml})$ was air-stripped by using an aerator of $80 \mathrm{l} / \mathrm{h}$ capacity. When the exhaust air from the column was bubbled through a second column containing $25 \mathrm{ml}$ tap water, it was found that the $\mathrm{X}$ was quantitatively transferred to the tap water in the second column after just more than $1 \mathrm{~h}$. The boiling point of the $\mathrm{X}$ evidently is below $25^{\circ} \mathrm{C}$ and at room temperature it is therefore present in a gaseous state.

\section{Conclusions}

The tests described above clearly show that the oxidation state of $\mathrm{X}$ plays a key role in biological phosphate removal as demonstrated by means of the batch activated sludge tests. Under anaerobic conditions $\mathrm{X}$ was present in the reduced state and this resulted in a chemical reaction with dissolved orthophosphate and the formation of $\mathrm{X}_{3} \mathrm{PO}_{4}$. The latter is believed to represent that portion of orthophosphate that is extractable with chloroform. It is also considered to be the phosphate species that is required for biologi- cal phosphate uptake. When $\mathrm{X}_{3} \mathrm{PO}_{4}$ is transformed by means of contacting it with $\mathrm{Fe}$ metal, phosphate uptake proved to be poor or non-existent. It is postulated that $\mathrm{X}_{3} \mathrm{PO}_{4}$ was changed to ordinary orthophosphate, i.e. $\mathrm{Na}_{3} \mathrm{PO}_{4}$, in the oxidation process, thus rendering it unsuitable for biological phosphate uptake.

The ascorbic acid method that was used to determine phosphate concentration does not distinguish between $\mathrm{X}_{3} \mathrm{PO}_{4}$ and ordinary orthophosphate. The only way to distinguish between the phosphate species (species that are suitable for biological phosphate uptake and the other orthophosphate species) is the fact that the former could be extracted with chloroform.

From the observations and initial laboratory tests the conclusion is made that biological phosphate removal operates in tandem with a chemical mechanism. The chemical reaction is responsible for the formation of an organic phosphate species that is considered to play the key role in the biological phosphate removal process. Without the formation of the yet-to-be-identified phosphate species, biological phosphate removal cannot take place. In other words, when the phosphate is not attached to the organic substance, there simply is no luxurious uptake or excess removal of phosphates, as demonstrated in the laboratory experiments.

\section{References}

BARNARD JL (1974) Cut P and N without chemicals. Water and Waste Eng. 11(7) 33-36.

FUHS GW and CHEN M (1975) Microbiological basis of phosphate removal in the activated sludge process for the treatment of wastewater. Microbial Ecol. 2 119-138.

GERBER A, MOSTERT ES, WINTER CT and DE VILLIERS RH (1986) The effect of acetate and other short chain carbon compounds on the kinetics of biological nutrient removal. Water SA 12 7-12.

GRADY (Jr.) CP Leslie, DAIGGER Glen T and LIM Henry C (1999) Biological Wastewater Treatment. Marcel Dekker, Inc. New York, Basel. 1076 pp.

LEVIN GV, TOPOL GJ, TARNAY AC and SAMWORTH RB (1972) Pilot plant tests of a phosphorus removal process. J. Water Pollut. Control Fed. 44 (10) 1940-1954.

NICHOLLS HA and OSBORN DW (1979) Bacterial stress: A prerequisite for biological removal of phosphorus. J. Water Pollut. Control Fed. 51 (3) 557.

STANDARD METHODS (1995) Standard Methods for the Examination of Water and Wastewater. $\left(19^{\text {th }}\right.$ edn.). Washington DC.

WENTZEL MC, CLAYTON JA, LILLEY ID, EKAMA GA, LOEWENTHAL RE and MARAIS GvR (1991) Consolidation of Activated Sludge and Water Chemistry Research. WRC Report No. 251/1/91. 